Arab World English Journal (AWEJ) Volume 12. Number1 March 2021

DOI: https://dx.doi.org/10.24093/awej/vol12no1.3

Pp. $28-39$

\title{
The Need for Translation in the Globalized World English Arabic Contact in the Algerian Academic Context
}

\author{
Hicham BENMOKHTARI \\ Faculty of Foreign Languages \\ University of Oran 2-Mohammed Ben Ahmed, Algeria \\ E-mail : benmokhtari.hicham@gmail.com
}

Received: 12/29/2020 Acceoted: 3/3/2021 Published: 3/24/2021

\begin{abstract}
The neck-breaking changes imposed by the process of globalization demand a reconsideration of the mundane scholarly dealings. The constant need for communication in a scientific area to keep pace with the continuing advancements and the newly published research works, mainly in the Speech-language Pathology branch, pushes the researcher to look for the appropriate tools which bridge the gap and ease the task. The researcher tries to find out how translation can bridge the gap between the technological improvements, anglicized data, and the actual context in which the Algerian students and teachers work? This research paper aims, thus, at researching the significance of translation from English to Arabic in an Algerian academic context (at the University of Oran 2). To reach the predetermined objective, the researcher uses of descriptive case study research in which a students' questionnaire, a teachers' interview, and program analysis are used. The findings show that a total absence of both the English language and translation in such a scientific discipline widens the gap between the requirements of the age and the actual practice enormously. A set of recommendations, including insertion of a specialized translation module, are suggested to help both the teachers and the students in this department.
\end{abstract}

Keywords: Algerian, academic, context, English, Arabic, language contact, globalized world, Speech-Language Pathology, translation

Cite as: BENMOKHTARI, H . (2021). The Need for Translation in the Globalized World English Arabic Contact in the Algerian Academic Context Arab World English Journal, 12 (1) 28 -39. DOI: https://dx.doi.org/10.24093/awej/vol12no1.3 


\section{Introduction}

Globalization is a process driven by international communication in different domains, including commerce and investment. It started as an economic process and pervaded every sphere of human activity. A global interaction and integration among people who look for suitable ways to connect is a direct result of such a process. Owing to the quick improvements in technologies, an understanding of our global world is required to keep up with the forces that had thrust upon us. This impacts the environmental, cultural, political, economic, educational, academic as well as physical well-being in societies.

Translation is getting recognition due to its extreme importance in a globalized world. We as part of the globe must consider it as an ally that helps us keep pace with the development of globalization, in the age of globalized knowledge, which is limited neither by space nor by time. The de facto language chosen universally is English, and the best way to spread this knowledge is through this language.

In an academic context and for the speakers of the other languages, whether in the advanced or third world nations, the imperative need for translating the latest researches and books in different fields must be highlighted. In Algeria, for instance, university teachers and students find it challenging to access world knowledge due to the policies imposed in the educational landscape. Thus, how can translation bridge the gap between the technological improvements, anglicized data, and the actual context in which the Algerian students and teachers work? To what extent can translation from English to Arabic and vice versa help researchers access the main published scientific productions in the globalized world?

For this, we try through the current research to analyze language contact between English and Arabic in an Algerian academic context, and then to reveal the continuous importance of translation.

The rational of this study is to highlight the role of translation fostering language contact between Arabic and English and thereby improving the students' understanding of the subject matter.

\section{Literature Review}

\section{English: An International Academic Language}

Besides its flexibility and easy grammar, nearly four to five million people used English during the reign of Queen Elizabeth I (1533-1603), it is now used by around 1.5 billion people to become a widely spoken language, (Crystal, 1999). After the Second World War USA purchased the world's gold and the gifted spirits that migrated from Europe escaping wars there, these two powerful motives led to US dominance over the global economy and knowledge (Genç \& Bada, 2010). Dieu (2005) states that exactly after the Treaty of Versailles, "English started being used in diplomacy and gradually in economic relations and the media"(p. 2). The huge American productions in different fields, including science, economy, art, and others, were exported to the outer world aided a great deal in the spread of English is chosen as the official language of business and science (Altbach, 2007). 


\section{English: The Language of Scholarly Communication}

Larivière (2018), an associate professor of information science at Montréal University, has enquired how and why the wave of Anglicization is sweeping throughout the social sciences and humanities, through an analysis of a vast corpus of articles indexed in Thomson Reuters' Web of Science database of more than 3,500 specialized journals. Larivière (2018, as quoted in the CAUT) asserted that publishing "in the natural and medical sciences field, the debate is a foregone conclusion. If we don't publish in English, we are not even on the map as researchers" he adds "University rankings only take into account the number of articles published in the most prestigious journals, and these are all in English. That's one of the main reasons why our universities are pushing us to publish in English.”(p. 1)

Within the last few decades, English has become one of the most important academic and professional tools. More than $90 \%$ of the indexed scientific productions are in the English language, for it is recognized as the essential language to learn by the international community. English is, in fact, the standard language in the international research community, especially in natural sciences (Bada \&Genç, 2010, Di Bitetti \& Ferreras, 2016).

English is thereby the language of scientific publication, considering the latest universities ranking. According to the three most reliable scientific institutions, including ARWU(Academic Ranking of World Universities) Shanghai ranking, Times Higher Education ranking, and QS World University Ranking, we can assume that the top ten universities are either from the USA or England where English is their publishing language.

\section{English in Algeria}

Algeria is a culturally and linguistically diverse North African country. Its population is around 42 million. There are two main linguistic communities in Algeria: Arab and Berbers. $70 \%$ of the Algerians speak different varieties known as colloquial or Algerian Arabic, while $30 \%$ consists of Berber including, the Chaoui, the Kabyles, the Mezab, and the Tuareg speak Berber variety (Chaker, 2007). Code-switching using a Berber variety and French or Algerian Arabic and French is common in Algeria.

English as a second foreign language is thought to have the potential to help raise the quality of education in Algeria and promote external mutual understanding and internal social progress since English was recognized as the language of science and technology. English in Algeria was supported by the British and the Americans in the 1980s by establishing the British Council and the American corner in Algiers, which also helped with teacher-training and provided scholarships for study in Britain. (Belmihoub, 2016)

The attempts of the ministry of national education in the mid-1990s to offer English as an option besides French in the fourth grade in primary schools, unfortunately, failed as most parents chose French over English for they thought French easier to acquire in Algeria. The government's move is because English is a tool to show solidarity with the Arabic-speaking Middle East (Belmihoub, 2018). The initially flourishing ELT industry and then its decline in Algeria in the 1900s ends in the actual resurrection of English reflects the competitive linguistic environment created by the cultural and academic programs which the British, French, and American embassies promote to 
spread their languages. In other words, English teaching competes French teaching since 2000(Miliani, 2000).

In universities, for instance, English was introduced as a module in many disciplines as a foreign language within the introduction of the LMD (Licence-Master-Doctorate) system. The programs focus on the students' needs and the language for special purposes objectives.

\section{The Place of Translation in the Algerian University in the Era of Globalization The Mother Tongue as a Basis for Language Education}

Atkinson (1987) provides three reasons for L1 use in ELT. First of all, the mother tongue is thought to be the learner's preferred strategy, especially for beginners and intermediate students (as cited in Harbord, 1992). Translation and transfer are natural strategies and inevitable processes a student use to avoid some problems; therefore, teachers should find systematic ways to employ them rather than struggling to keep them away. L1 is also perceived as a time-saving technique when explaining certain aspects. Further, giving students a chance to use their mother tongue is humanistic in that it helps them to express themselves clearly and fuel their motivation to learning at the same time, it allows them to involve in the process of language construction.

\section{Translation in the Algerian University}

"Algeria was, in fact, one of the first Arab countries that started to deliver translation at university as a separate independent discipline at the Institute of Translation" (Goui, 2016).Translation was integrated in the Algerian university since 1943 at the faculty of arts human sciences in the University of Algiers. Due to the ministerial decree 73-139, an institute was created. Shortly after establishing of the institute an administrative change transformed it into an independent department in the faculty of foreign languages in the Algerian universities (Benouda, 2020). In 2010, all the translation departments were closed to become a module in the faculty of foreign languages except some universities where it remains a department (Batna, Constantine, Annaba, Tlemcen). Two national institutes were established in Algiers and Oran.

\section{Translation in the Academic Context}

In an Algerian context, we notice an absence of translation in most of the branches of human and social sciences except in the Arabic department and foreign languages department (French, English, Spanish) for $2^{\text {nd }}$ and $3^{\text {rd }}$-year license degrees and some master degree specialties as an optional module with lower credits and coefficients. The main objective of translation here is to improve the language.

In medical, natural, and technical sciences, we note a total absence of translation. Here, the problem lies, the students' mother tongue is Arabic, and he learns either in Arabic or in French. However, in the globalized world, the student researcher is in urgent need for translation as a key to access knowledge that is generally produced in the English language. The following sections will present the importance of such a discipline in bridging the gap between Arabic and English.

\section{Methodology}

The researcher used descriptive research to probe the status of the global language, English, and translation in an academic context. A case study was then conducted to find out whether the 
hypothesis is true or not. Both quantitative as well as qualitative research tools were employed to ensure triangulation and thereby to seek reliable findings. The researcher has designed a students' questionnaire, where 30 Master students from the Speech Language Pathology (SLP) branch at the University of Oran 2 in Algeria were questioned, and an interview for five (05) teachers in the same department. An analysis of the administered program followed to unveil reality.

\section{Participants}

The researcher has chosen second-year Masters from the department of psychology as a case study. Five teachers from the same department were interviewed to collect the raw data, as shown in the following table.

Table1. Research Participants

\begin{tabular}{|l|l|l|}
\hline Participants & Males & Females \\
\hline Teachers & 3 & 2 \\
\hline Students & 12 & 18 \\
\hline
\end{tabular}

\section{Instruments}

The teachers' interview and the students' questionnaire included two main sections. The first one is composed of four questions aimed at probing the status of the English language in the Algerian university. The second section is devoted to find out the significance of translation to ease the mundane academic practices. The program imposed by the ministry of higher education was then analyzed to find out whether Arabic English contact is ensured or not.

\section{Data Analysis}

The status of the English language in Algerian universities

1. The language used in writing the latest researches in the SLP field

The result is as follows: $70 \%$ respond that Arabic is used most often to conduct studies, $23 \%$ answer: French, while the tiny minority represents $7 \%$ of the whole state that English is indeed the language of science and thereby of the newest researches. Accordingly, the majority of the students are not aware of the importance of English, which is the most widely used language in their field of interest, and they do not read in English; this is because they study either in Arabic or in French.

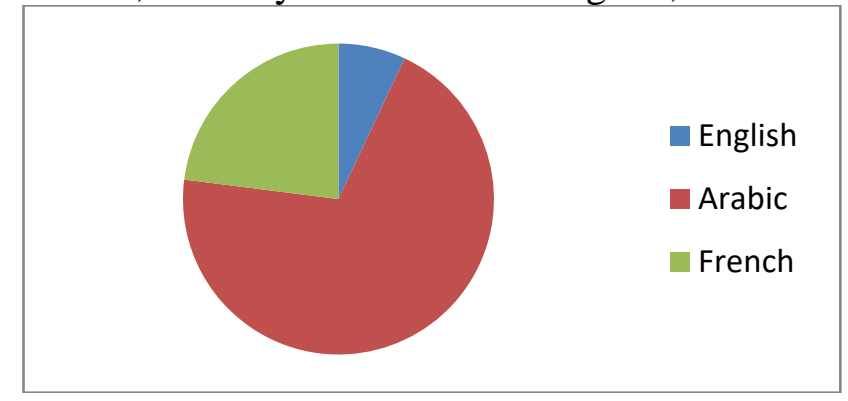

Figure1. The use of the English language in conducting researches 
According to the results, $7 \%$ of our respondents answer yes, while $93 \%$ state that they do not use English in researching. This confirms their tendency towards Arabic and French in the first question.

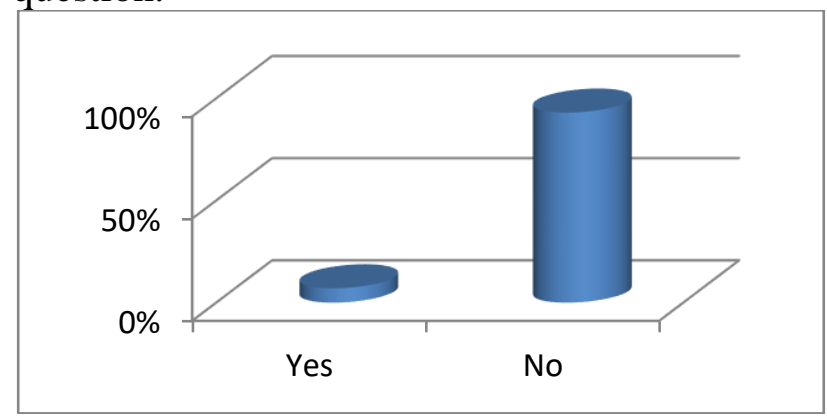

Figure2. The way English is used in researches

The tiny minority that answered with yes most often reads articles in English or researches the important websites and, when needed, uses translation to understand better.

2. The students level in the English language

$2 \%$ of the informants claim that their English level is good, 5\% reckon that they are average, and $93 \%$ say that they are weak. The findings reflect that there is always a split between what to be taught or learned and how to approach or collect the latest data in the domain.

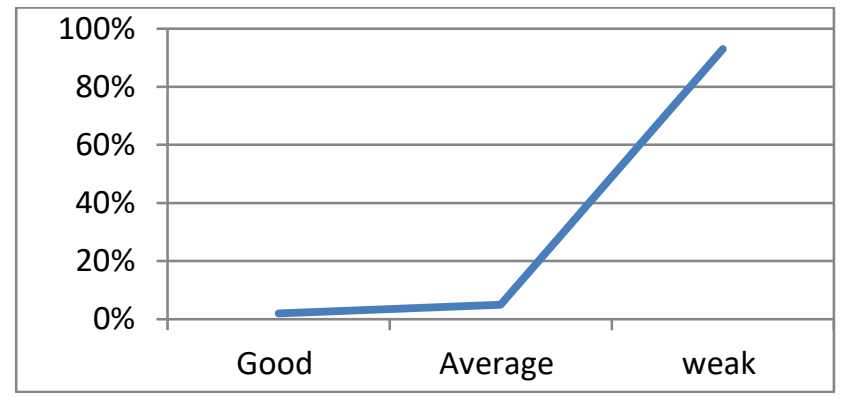

Figure3. The main tools which enable the student in their studies

A. Translation: a handy tool in improving scholarly communication

According to this item, the majority of the students (67\%) is opting for translation or seeks help from translators to find the exact equivalents for the concepts and terminology used in the field. $27 \%$ ask their teachers to understand better. $6 \%$ are not interested in improving their knowledge. The practical use of translation demonstrates its importance though not used officially in their studies.

1. Knowing the equivalent of the specialty in the English language

The majority of the students and who represent $73 \%$, do not know the equivalent of their specialty in English, but they know it in Arabic and French that indicates their deep ignorance of an important concept in English, so what about the remaining concepts and terms. This indeed widens the gap between their actual knowledge and the significant novelties in their domain. 
Translation here can play an essential role in bridging the gap and keeping pace with the quick advancements.

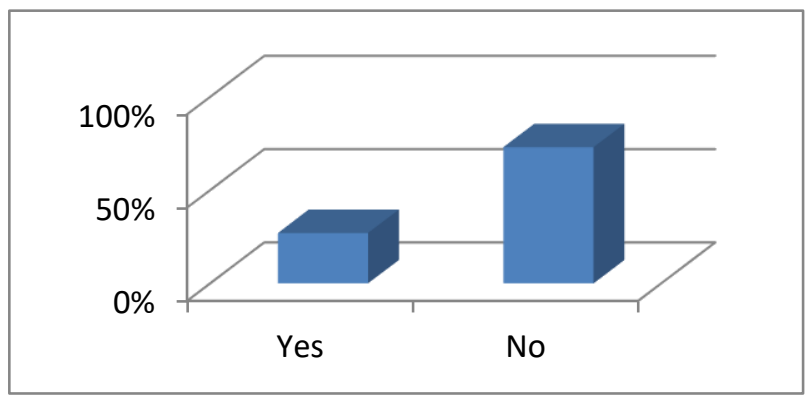

Figure4. The translation of the references in the mother tongue

$70 \%$ of the respondents are aware of the imperative need for intensifying the translation of the resources into Arabic, for they are very scarce. The students are in need of references in their mother tongue. Speech -Language Pathology is a relatively new branch of science which most of its researches are written in the first place in English than in French and some other languages. Table2. The language of the Resources Students Read

\begin{tabular}{|r|r|}
\hline References & Statistics \\
\hline Available & $70 \%$ \\
\hline Not available & $30 \%$ \\
\hline
\end{tabular}

The majority of the students $(80 \%)$ prefer reading the important references in their native language, while only $20 \%$ of the informants read them in French. This denotes that, first, they cannot use the English language, in the short and medium-term, as a tool to research and, second, they need a translated version of the latest studies into their mother tongue and then into French.

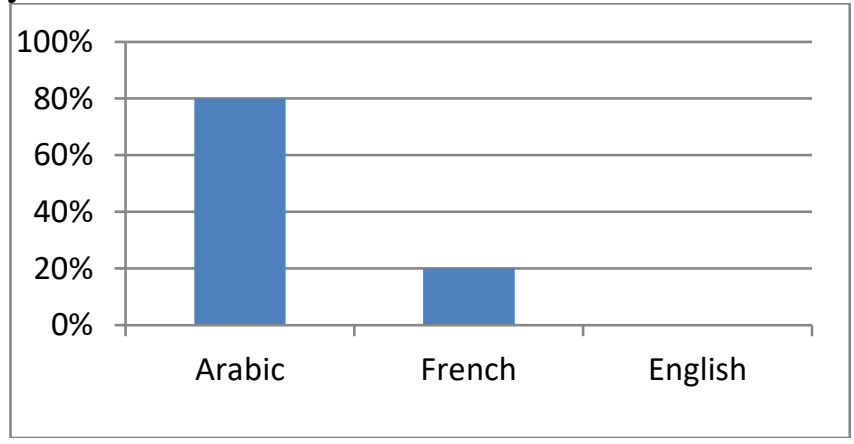

Figure5. The Language Students Use

1. The Solution Students Resume to when they Encounter an Interesting English Resource

The majority of the respondents $(77 \%)$ resort to Google Translate to read an important book or article in their area of interest in English, while, $6 \%$ of the questioned students ask the help of a 
specialized translator. For this reason, we recognize the continuing importance of translation in their educational journey. The absence of translation and a systematized policy translation in the official program at university and the ministry drives backward results that are not pedagogical at all.

Table3. Students' Solutions

\begin{tabular}{|l|r|}
\hline The solution & Statistics \\
\hline I read it myself because I understand English & $17 \%$ \\
\hline $\begin{array}{l}\text { I translate it myself using Google translate or other tools of automatic } \\
\text { translation }\end{array}$ & $77 \%$ \\
\hline I ask the help of a translator & $06 \%$ \\
\hline
\end{tabular}

2. The ways, according to the students, translation can be used to carry on studies

All the students agreed on the importance of translation and their need for necessary references to fulfill the Master dissertation. They indicate that translation into Arabic at the level of concepts and terminology is very important. Thus, they suggest the inclusion of translation modules in the License and Master programs and translating a larger number of resources into Arabic, the language that they prefer to read in.

\section{The Teachers' Interview}

Two of the teachers state that the English language aids them a lot in carrying on their studies related to Speech-Language Pathology, for it was founded for the first time in the USA in 1932. Three of them affirm that, as Algerian teachers, they refer to French resources for their research is based on the French school, and they do not master the English language. Besides, all of the respondents that most of the important references are produced in English, especially in the field of language disorder, psycholinguistics, neurolinguistics, and developmental psychology.

They also reckon that the English language, unfortunately, is not used in conducting scientific researches for the teachers and the students do not master the language. In the field of Language Pathology, for instance, most of the second-year master modules require the use of the latest resources that are written in the English language. The researchers are thus obliged to translate the French versions into Arabic as they understand it. The students cannot use English resources because they cannot understand and translate English texts. In their entire career, they rely on French as an intermediary for translation.

All of the respondents declare that there is no English Arabic dictionary specialized in Language Pathology to be used as pedagogical support, Two of the informants confirm that they generally translate texts and the most important terms and concepts from English to Arabic while the others use the French as an intermediary language to translate and understand the resources, and most often they use translation software such as deepl.com so, when asked about the solution that helps both the students and the teachers, our respondents suggest that implementing a module of specialized translation, particularly from English to Arabic, of the terminology or the concepts in the field aids a great deal.

Translation accordingly bridges the gap in our globalized atmosphere where researchers and specialists have to keep pace with the continuing scientific advancements in speech therapy and 
language pathology. They suggest an urgent inclusion of a specialized translation in all the pedagogical research teams for master studies.

\section{Program analysis}

Through the analysis of the official program of the Language Pathology and Communication specialty Master 2, which spans for one semester composed of 16 weeks, an equivalent of 337.30 hours. The weekly volume of hours is divided into TD sessions (10.5 hours) and lectures (12 hours). We can observe a total absence of the English language, translation, or even a module to teach the main terminology and concepts or their translations. We recognize only a module in the transversal unit, which is French as a foreign language taught 22, 30 hours per semester, around $6.5 \%$ of the total. This semester is a primary preparation for a dissertation that the students are supposed to be produced by the end of their Master studies.

It can be seen that Arabic is the language of scholarly dealings in all the modules. There is an ignorance of the importance of the English language and translation. They are the basis for the preparation and training of the enthusiastic students' researchers to their scientific journey. The students are deprived of the most essential tools for scientific research in the era of globalized thoughts, science, and knowledge.

\section{Discussion of the Results}

The data collected show that there is a great gap between the real academic context where French pervades all the student-teacher contact and the required methods to ensure an up-to-date understanding of the major findings in the domain of Speech-Language Pathology. The researcher, thus, should highlight the necessary requirements to aid students and teachers keep pace with the constant improvements.

\section{Conclusion}

The study probed primarily the relevance of translation in strengthening English-Arabic language contact in a globalized world where science is continuously evolving. The findings of the students' questionnaire, the teachers' interview, and the program analysis pulled up that the gap between English, the language of knowledge, and scientific research, and Arabic, their native language, is so deep. Both of the students and teachers agreed upon the significance of translation to approach the latest findings and data in their area of interest. They are deeply aware of the impact of the absence of translation as a governmental and a pedagogical policy in the Algerian university in general and in their specialty in particular.

Accordingly, the researcher suggests the following recommendations:

1. The foundation of a national center for academic translation belongs to the ministry of higher education.

2. The integration of translation modules in the Master degree program to translate the important concepts and terminology from English to Arabic.

3. Editing specialized bilingual dictionaries in the Language pathology domain.

4. It is time to reactivate the role of translation in an academic context as a research tool, especially in the field of Language pathology. 
Arab World English Journal (AWEJ) Volume 12. Number 1. March 2021

The Need for Translation in the Globalized World

BENMOKHTARI

\section{About the Author;}

Dr. BENMOKHTARI, Ph.D. He had got his doctorate degree in translation studies 2014-2018 from the University of Tlemcen. Algeria. BENMOKHTARI is now a lecturer at Oran 2 university. He teaches a wide variety of courses including introduction to translation studies and specialized translation. ORCiD: https://orcid.org/0000-0002-97927894

\section{References}

Al Nofaie, H. (2010). The Attitudes of Students and Teachers Towards Using Arabic in EFL Classrooms in Saudi Republic Schools: a Case Study. Novitas Royal (Research on Youth and Language) 4(1), 64-95

Altbach, P. (2007). The Imperial Tongue: English as the Dominating Academic Language. Economic and Political Weekly, 42(36), 3608-3611. Retrieved from http://www.jstor.org/stable/40276356

Belmihoub, K . 2018, English in a multilingual Algeria. World Englishes. Retrieved from https://www.researchgate.net/publication/322698150

Benouda, A. (2020). Mot de la Directrice de l'Institut de Taduction. Retrieved from http://traduction.univ-alger2.dz/index.php/fr/

Butzkamm, W. (2003). We only learn language once. The role of the mother tongue in FL classrooms: death of a dogma. Retrieved from: http://www.fremdsprachendidaktik.rwthaachen.de/Ww/programmatisches/pachl.html .

Chaker, S. (2007). Langue (berbère) [Berber language]. In G. Camps \& S. Chaker (Eds.), Encyclopédie Berbère XXVIII-XXIX-L7 (pp. 4348-4360). Paris: Peeters Publishers

Crystal, D. (1999). A Thousand Years of English. Retrieved from http://www.davidcrystal.com/DC_articles/English24.pdf

Di Bitetti, M. S., \& Ferreras, J. A. (2017). Publish (in English) or Perish: The Effect on Citation Rate of Using Languages other Than English in Scientific Publications. Ambio, 46, 121127. https://doi.org/10.1007/s13280-016-0820-7

Dieu, B. (2005). Some Facts and Figures About the English Language. Retrieved, from http://the_english_dept.tripod.com/esc.html

Genç, B. \& Bada, E. (2010). English as a World Language in Academic Writing. Retrieved from https://www.readingmatrix.com/articles/sept_2010/bilal_genc.pdf

Goui, J. (2016). Updating Translation Curriculum in Algeria. Retrieved from

Harbord, J. (1992), The use of the Mother Tongue in Classroom. ELT Journal 46/4: Oxford University Press.

http://isat-al.org/Main_Ar/portfolio-item/updating-translation-curriculum-in-algeria/

Larivière . V, 2018, The Dominant Language of Science. Retrieved from https://www.caut.ca/bulletin/2018/02/dominant-language-science

Miliani, M., (2000), Teaching English in a multilingual context: The Algerian case, Mediterranean Journal of Educational Studies, 6(1). 13-29.

Wharton, C. (2007). Informed Use of the Mother Tongue in the English Language Classroom, Retrieved from http://www.birmingham.ac.uk/documents/college . 


\section{Appendices}

\section{Appendix A: Students' Questionnaire}

The following questionnaire is designed to find out the importance of translation in the academic context and the urgent need for such a process to successfully write and communicate in a scholarly community successfully. I will be grateful if you accept to answer these questions.

A. The status of the English language in Algerian universities

1. What is the language that is mostly used in writing the latest researches in your field of interest?

$$
\text { ما هي اللغة الأكثر استخداما في كتابة احدث البحوث في ميدان اهتمامك و بحنك العلمي ؟ }
$$
a. English
b. Arabic
c. french

2. Do you use English in preparing your courses or conducting your researches?
a. Yes
b. No

$$
\text { هل تستخدم اللغة الانجليزية في تحضير دروسك أو إنشاء بحوثلك؟ }
$$

3. If yes, in what ways?

4. What do you think of your level in English?

$$
\text { إذا نعم حدد كيف تستخدمها؟ }
$$

$$
\text { كيف تقيم مستو اك في اللغة الانجليزية؟ }
$$

5. What are the tools that enable you to access the latest productions in your field?

$$
\text { ما هي الوسائل التي تساعدك في فهم أخر الإصدارات في مجالك؟ }
$$

B. Translation: a handy tool in improving scholarly communication

1. Do you know the equivalent of your specialty in English? Name it?

$$
\text { هل تعرف المقابل لتسمية تخصصك باللغة الانجليزية،اذكره؟ }
$$
a. Yes
b. No

2. What do you think of translating the significant references to your mother tongue?

$$
\text { ما رأيك في ترجمة أهم المصادر إلى لغتلك الأم؟ }
$$
a. Not available
b. Available

3. In which language do you prefer reading resources?
a. Arabic
b. French
c. English

$$
\text { بأي لغة تفضل قر اءة المر اجع في اختصاصك؟ }
$$

4. In case you encounter an interesting book written in English, what do you do?

a. You translate it yourself

$$
\text { في حالة ما إذا صـادفت كتابا مهما ماذا تفعل؟ }
$$

b. You use Google translate or other tools of automatic translation

c. Or you ask help of a translator

5. According to you, in what ways can translation help you carry on your studies?

$$
\text { في رأيك كيف يكن للترجمة أن تساعدك في مو اصلة بحوثلك؟ }
$$

\section{Appendix B: Teachers' Interview}

A. The status of the English language in Algerian universities 
1. What is the role of the English language in your knowledge construction in your field of interest?

2. In which language are the latest and important researches written?

3. How do you perceive English as a language of research in the Algerian university in general and in the language pathology specialty in particular?

4. Do you recommend to your students to read resources in the English language?

B. Translation: a Handy Tool in Improving Scholarly Communication

1. Are there any specialized bilingual dictionaries (eng-ar) in SLP?

2. Do you use translation from English to Arabic at a terminological and conceptual level?

3. In case you need translation in your teaching, what are the tools that you use?

4. What do you think of the integration of translation modules in the Master degree?

5. What is the significance of translation in bridging the gap between English and Arabic for your students the continuing scientific improvements in the globalized world? 